\title{
SOIL NITROGEN APPLICATION IN THE SPRING DID NOT INCREASE APPLE YIELD ${ }^{1}$
}

\author{
APLICAÇÃO DE NITROGÊNIO AO SOLO NA PRIMAVERA NÃO \\ AUMENTA O RENDIMENTO DE FRUTOS DE MACIEIRA
}

\author{
Paulo Roberto Ernani ${ }^{2}$ Jaques Dias $^{3}$
}

\section{SUMMARY}

Since there is no chemical method to assess $N$ availability from field soil samples, this nutrient is still recommended based on regional field trials. This study aimed to evaluate the effect of spring application of $N$ to the soil on fruit yield of apple cultivars. Two experiments were carried out respectively for 'Gala' and 'Fuji'. The trees, grafted on MM 106 rootstock, were planted in 1987, spaced $4.50 \times 1.80 \mathrm{~m}$, in a clayed Oxisol (Hapludox) with $4.0 \%$ of organic matter, in Vacaria (RS), Southern Brazil. Treatments were applied annually, from the spring of 1990, in the tree row, over a 1.5-m-wide strip, as urea, and consisted of four rates of $N$ corresponding to $0,27.5,55.0$ and $82.5 \mathrm{~kg} \mathrm{ha}^{-1}$ in the first three years, and respectively $0,50,100$ and $120 \mathrm{~kg} \mathrm{ha}^{-1}$ in the remaining two years. Data were collected for four years, starting at the 91/92 growing season. Application of increasing rates of $N$ to the soil during five years had no effect on fruit yield and on concentration of $N$ in the leaves regardless of year and cultivar. Average annual fruit yield varied from 50 to $70 t \mathrm{ha}^{-1}$ for 'Gala' and from 39 to $89 \mathrm{t} \mathrm{ha}$ '-1 for 'Fuji', but in the entire period the average yield was similar for both cultivars, approximately 56t hal. Concentration of $N$ in the leaves was always in the normal range (2.0 to 2.5\%) for 'Fuji', and slightly lower for 'Gala', but above 1.9\%. Total $N$ requirement for tree growth and fruiting, thus, came from soil organic matter decay.

Key words: apple yield, nitrogen, 'Gala', 'Fuji'.

\section{RESUMO}

Como não existe método químico eficiente para avaliar a disponibilidade de $\mathrm{N}$ a partir de amostras de solo, a recomendação desse nutriente é ainda obtida a partir de curvas de resposta em experimentos regionais. $O$ presente trabalho objetivou avaliar o efeito do $N$, aplicado ao solo na primavera no rendimento de frutos de cultivares de macieira. Foram conduzidos dois experimentos, respectivamente com os cultivares Gala

\begin{abstract}
e Fuji, desenvolvidos sobre porta-enxerto MM 106. As árvores foram plantadas em 1987, espaçadas de 4,5 x 1,80m, num Latossolo bruno argiloso, com 4,0\% de matéria orgânica, localizado em Vacaria (RS). Os tratamentos foram aplicados anualmente, durante a primavera, na forma de uréia, e consistiram de doses crescentes de $N$ mineral equivalentes a $0,27,5,55$, e $82,5 \mathrm{~kg} \mathrm{ha}^{-1}$ nos três primeiros anos, e respectivamente 0, 50, 100 e $200 \mathrm{~kg}$ $h^{-1}$ nos dois últimos anos. A uréia foi aplicada numa faixa de $1,5 \mathrm{~m}$ de largura ao longo da fila de plantio, sobre a superfície do solo, sem incorporação. A aplicação de $N$ ao solo na primavera não afetou o rendimento de frutos e a concentração de $N$ nas folhas, independente do ano ou do cultivar. A produtividade média anual de frutos variou de 50 a $70 t \mathrm{ha}^{-1}$ para a Gala e de 39 a $79 t$ ha $^{-1}$ para a Fuji. Na média dos quatro anos, porém, a produtividade foi semelhante para os dois cultivares, aproximadamente $56 \mathrm{t} \mathrm{ha} \mathrm{a}^{-1}$. A concentração de $\mathrm{N}$ nas folhas ficou sempre dentro da faixa normal (2,0 a 2,5\%) para a Fuji; para a Gala os valores foram um pouco mais baixos, porém sempre acima de 1,9\%. A necessidade de $N$ para o desenvolvimento das árvores e para a frutificação foi, portanto, completamente suprida pela decomposição da matéria orgânica do solo.
\end{abstract}

Palavras-chave: macieira, nitrogênio, Gala, Fuji.

\section{INTRODUCTION}

Nitrogen is the plant nutrient that most concern has caused to growers and soil scientists due to its impacts on plant growth, fruit quality, and environment.

Monitoring soil N availability is fundamental for apple production. An adequate level of $\mathrm{N}$ contributes to fruit set, fruit quality, tree growth

\footnotetext{
${ }^{1}$ This study was supported by Agropecuária Schio Ltda.

${ }^{2}$ Engenheiro Agrônomo, PhD., Professor da Universidade do Estado de Santa Catarina, CP 281, 88502-970 - Lages, SC, Brasil. Pesquisador do CNPq. E-mail: prernani@ cav.udesc.br. Autor para correspondência.

${ }^{3}$ Engenheiro Agrônomo, Agropecuária Schio Ltda, Vacaria RS.
} 
and yield (STILES, 1994), whereas its restriction negatively affects all these parameters (STILES, 1994; MILLARD \& THOMSON, 1989), and increases the tendency toward biennial cropping (FAUST, 1989; STILES, 1994). Excess of $\mathrm{N}$ is also detrimental to this culture because it promotes excessive shading, interferes with the development of fruit red color, reduces the firmness of fruits (STILES, 1994) and fruit storage life due to increases on fruit respiration rate (FAUST \& SHEAR, 1972) and the development of several physiological disorders including bitter pit, cork spot, and internal breakdown (STILES, 1994). Normal rates of $\mathrm{N}$ had no effect on storage life and fruit quality (WOLK et al., 1998). Since the cost of $\mathrm{N}$ is low relatively to the total apple orchard production cost, growers normally apply it in excess (WEINBAUM et al., 1992; TAGLIAVINI et al., 1996) in order to make sure it is not going to limit crop yield and tree growth.

The highest $\mathrm{N}$ requirement for apple trees seems to be in the spring, during cell division. Nitrogen application at this time stimulates canopy growth and fruit enlargement. Nitrogen is also recommended to be applied in the summer or early in the fall, after fruit harvest, in order to raise $\mathrm{N}$ content of the developing blossoms (TUKEY, 1985) and tree reserves (O'KENNEDY et al., 1975). High availability of $\mathrm{N}$ at this time does not promote excessive shoot growth or negative effects on fruit color and quality, but helps to keep leaves green longer, that contributes to carbohidrate accumulation. Time of $\mathrm{N}$ application on apple orchards, however, has not influenced fruit yield (LORD et al., 1981; ERNANI et al., 1998) or fruit quality (LORD et al., 1981).

Nitrogen recommendation for apples in Southern Brazil does not specify rates of $\mathrm{N}$ to be applied. It is suggested to take into consideration many soil and plant aspects such as tree vigor, productivity, $\mathrm{N}$ concentration in the leaves, soil organic matter content, and symptoms of $\mathrm{N}$ deficiency (COMISSÃO DE FERTILIDADE DO SOLO, 1995). This is too general and does not contribute so much to agronomists and growers to decide the amount of $\mathrm{N}$ to be applied because it is not mentioned any number to serve as initial parameter. The difficulty in making such recommendation for apple orchards arises from the lack of a soil chemical method to assess $\mathrm{N}$ availability from soil samples, from the large number and magnitude of soil reactions that affect $\mathrm{N}$ availability and its fluctuation over time, and from the perennial habit of apple trees that allows them to uptake $\mathrm{N}$ all over the year and to accumulate it for later use. Thus, rates of $\mathrm{N}$ to be applied must be obtained from local field trials.

This study aimed to evaluate yield response of apple cultivars ('Gala' and 'Fuji') to annual $\mathrm{N}$ application to the soil in the spring in a four years study.

\section{MATERIAL AND METHODS}

The study was conducted in Vacaria, Rio Grande do Sul State, from September of 1990 until June of 1995. It comprised two individual trials, respectively for the cultivars 'Gala' and 'Fuji'. Both experiments were located in a commercial orchard on an Oxisol (Hapludox) that had, in the plow layer (0 - 20cm depth), water $\mathrm{pH}$ of 6.8 , labile $\mathrm{P}$ (Mehlich1) of $12 \mathrm{mg} \mathrm{kg}^{-1}$, exchangeable $\mathrm{K}$ of $200 \mathrm{mg} \mathrm{kg}^{-1}$, $55 \%$ of clay, and $4.0 \%$ of organic matter (O.M.). The trees, grafted on MM 106 rootstock, were planted in 1987, spaced $4.50 \mathrm{~m}$ (between rows) $\mathrm{x}$ $1.80 \mathrm{~m}$ (within row), performing 1,234 trees $\mathrm{ha}^{-1}$. 'Fuji' trees were used to pollinate the 'Gala' orchard, and 'Gala' trees to pollinate the 'Fuji' orchard, in a percentage of $14 \%$ of pollinator trees.

Treatments consisted of increasing rates of $\mathrm{N}$. They were applied in the spring, at full bloom, over the soil surface, in a 2.0-m-wide strip on the planting row, as urea, without incorporation into the soil. Nitrogen annual rates were 0, 27.5, 55.0 and $82.5 \mathrm{~kg} \mathrm{ha}^{-1}$ during the first three years, from 90/91 growing season, and then increased respectively to $0,50,100$ and $200 \mathrm{~kg} \mathrm{ha}^{-1}$ in the last two seasons evaluated (93/94 and 95/95). Treatments were arranged in a randomized complete block design with four replicates. Each experimental unit had six trees, distributed in the row, and only the four central trees in each plot were used for the determinations, that consisted of fruit yield and concentration of $\mathrm{N}$ in the leaves. Fruit yield was not recorded in the first season (90/91) because trees were young and crop load was under $10 \mathrm{tha}^{-1}$.

All fruits on the trees evaluated were harvested and weighted. 'Fuji' fruits were harvested all at the same time while 'Gala' fruits were harvested in two picks, spaced approximately 20 days. To express fruit yield, it was considered that pollinators and the main variety had the same productivity. Ten leaves per tree were collected about 110 to 125 days after full bloom, at the mid portion of the current season growth. They were oven-dried to constant weight, grounded, and wet digested with sulfuric acid plus hydrogen peroxide, according to ADLER \& WILCOX (1985). Total N 
in the leaves was determined by steam distillation in a semimicro-Kjeldahl equipment, according to TEDESCO et al. (1985).

The experimental areas had the same management practices used in the commercial orchard, including application of fertilizers (except $\mathrm{N}$ ), herbicides, insecticides, and fungicides, winter and summer pruning, hand thinning, and mineral oil plus Hydrogen Cyanamid to stimulate bud break. Since ground cover management system may affect N availability (MERWIN \& STILES, 1994), a 2.0$\mathrm{m}$-wide herbicide strip was kept free of cover sod.

Regression analysis were used to evaluate apple response to $\mathrm{N}$ applied and concentration of $\mathrm{N}$ in the leaves.

\section{RESULTS AND DISCUSSION}

Apple yield was not affected by $\mathrm{N}$ addition. Application of increasing rates of $\mathrm{N}$ to the soil in the spring did not increase fruit yield for 'Gala' or 'Fuji' in any of the four seasons evaluated. In the first two years we applied $\mathrm{N}$ up to $82.5 \mathrm{~kg} \mathrm{ha}^{-1}$ year $^{-1}$. Since there was no response to $\mathrm{N}$ applied in these seasons, and since the orchard was still at the initial phase of development, we increased $\mathrm{N}$ rates up to $200 \mathrm{~kg} \mathrm{ha}^{-1}$ year $^{-1}$ from $93 / 94$ growing season, but apple response remained the same, that is, there was no increase on fruit yield due to $\mathrm{N}$ application to the soil (table 1).

Table 1 - Fruit yield of 'Gala' and 'Fuji' as affected by addition or not of annual rates of $\mathrm{N}$ to the soil in the spring. Average of four replicates.

\begin{tabular}{|c|c|c|c|c|c|}
\hline \multicolumn{6}{|c|}{ Growing season } \\
\hline \multirow[t]{2}{*}{$\mathrm{N}$ added $*$} & $91 / 92$ & $92 / 93$ & $93 / 94$ & $94 / 95$ & Average \\
\hline & \multicolumn{5}{|c|}{ 'Fuji' } \\
\hline No & 39.1 & $\ldots$ & 82.7 & 38.5 & 53.4 \\
\hline N1 & 39.0 & $\ldots$ & 90.3 & 36.8 & 55.4 \\
\hline $\mathrm{N} 2$ & 45.3 & $\ldots$ & 92.5 & 43.0 & 60.3 \\
\hline N3 & 38.1 & $\ldots$ & 92.2 & 36.6 & 55.6 \\
\hline \multirow[t]{2}{*}{ Average } & 40.4 & & 89.4 & 38.7 & 56.2 \\
\hline & \multicolumn{5}{|c|}{ 'Gala' } \\
\hline No & 47.7 & 48.5 & 81.1 & 43.8 & 55.3 \\
\hline N1 & 56.8 & 56.8 & 83.8 & 57.8 & 63.8 \\
\hline $\mathrm{N} 2$ & 48.4 & 47.2 & 71.5 & 48.1 & 53.8 \\
\hline N3 & 58.2 & 53.4 & 78.5 & 50.2 & 60.1 \\
\hline Average & 52.8 & 51.5 & 78.7 & 50.0 & 58.2 \\
\hline
\end{tabular}

*N started to be applied in the spring of 90/91 growing season at rates respectively of $0,27.5,55.0$ and $82.5 \mathrm{~kg} \mathrm{ha}^{-1}$ until $92 / 93$ growing season; afterwards they were increased respectively to $0,50,100$ and $200 \mathrm{~kg} \mathrm{ha}^{-1}$ *** Regression coefficients were not significantly different at $\mathrm{P}=0.05$ for any cultivar, regardless of season.
Fruit yield was very good. The mean productivity obtained for the entire period evaluated was greater than $55 \mathrm{tha}^{-1}$, and similar for both cultivars. However, yield varied among years, and the magnitude of the fluctuation was higher for 'Fuji' than for 'Gala' (table 1). Average annual fruit yield varied from 50 to $70 \mathrm{tha}^{-1}$ for 'Gala', and from 39 to $89 \mathrm{t} \mathrm{ha}^{-1}$ for 'Fuji'. The highest crop load occurred at 93/94 growing season, where it was approximately 80t ha ${ }^{-1}$ for 'Gala' and $90 \mathrm{t} \mathrm{ha}^{-1}$ for 'Fuji'. In the following season (94/95): It was obtained the lowest yield of the experimental period, approximately 40t ha ${ }^{-1}$ for 'Gala' and $50 \mathrm{t} \mathrm{ha}^{-1}$ for 'Fuji' (table 1). A year with heavy crop load followed by a year with lower yield was also observed for 'Gala' with yield above 100t ha $\mathrm{ha}^{-1}$ (ERNANI et al., 1998), but it was not observed for this same cultivar with fruit yield up to approximately 40t ha ${ }^{-1}$ (ERNANI et $\boldsymbol{a l} ., 1997$ ) and for 'Fuji' with fruit yield up to 40t ha ${ }^{-1}$ (ERNANI $\boldsymbol{e}$ al., 1997) or 70t ha ${ }^{-1}$ (ERNANI et al., 1998).

Total $\mathrm{N}$ requirement for tree growth and fruiting, even on years with very high yields, was then supplied by native soil $\mathrm{N}$, probably coming from decomposition of stabilized organic matter and other plant residues. ERNANI et al. (1997) calculated that approximately $110 \mathrm{~kg} \mathrm{ha}^{-1}$ of $\mathrm{N}$ is released in a period of nine months from the decomposition of organic matter in the top layer of $0.3 \mathrm{~m}$ in this soil. If the amount of $\mathrm{N}$ removed by apple fruits, $0.5 \mathrm{~kg} \mathrm{t} \mathrm{t}^{-1}$ of fruit (WEINBAUM et $\boldsymbol{a l} .$, 1992), is valid for Brazilian conditions, the maximum $\mathrm{N}$ required in the present study would be always less than $50 \mathrm{~kg} \mathrm{ha}^{-1}$ year ${ }^{-1}$, that is much lower than the amount of $\mathrm{N}$ released from the soil O.M. calculated above.

Absence of fruit yield increments on apple cultivars due to soil $\mathrm{N}$ application was also observed in other experiments conducted in Southern Brazil, for Golden Delicious (BASSO \& SUZUKI, 1992) and for 'Gala' and 'Fuji' (ERNANI et al., 1997; ERNANI et al., 1998). In these studies it was evaluated yield response to $\mathrm{N}$ applied in the spring, up to $160 \mathrm{~kg} \mathrm{ha}^{-1}$ year $^{-1}$ (BASSO \& SUZUKI, 1992), in post-harvest, up to $60 \mathrm{~kg} \mathrm{ha}^{-1}$ in plots that received $40 \mathrm{~kg} \mathrm{ha}^{-1}$ year $^{-1}$ in the spring (ERNANI et al., 1997), and in different vegetative stages, split or not, at rate of $90 \mathrm{~kg} \mathrm{ha}^{-1}$ (ERNANI et al., 1998). In this last study, fruit yield was greater than $100 \mathrm{t} \mathrm{ha}^{-1}$ in some years. 
The systematic lack of fruit yield increment due to $\mathrm{N}$ addition in this region may be associated with low $\mathrm{N}$ requirement for these specie (WEINBAUM et al., 1992), with good conditions for $\mathrm{N}$ release from soil organic matter, and with poor conditions for $\mathrm{N}$ leaching. The amount of $\mathrm{N}$ released from the soil varies with soil organic matter content and with good conditions for microorganisms activity, which include soil $\mathrm{pH}$ above 5.5, availability of nutrients, and presence of adequate rates of oxigen and moisture in the soil. In all studies mentioned above, soil organic matter was always equal or above $40 \mathrm{~g} \mathrm{~kg}^{-1}$, soil $\mathrm{pH}$ above 6.0 , and there was no limitation on nutrient availability. In addition, moisture content in these soils is almost always high, but not excessive, due to the amount of annual rainfall (approximately $1500 \mathrm{~mm}$ ) and its good distribution over the year, due to the high clay content (above $500 \mathrm{~g} \mathrm{~kg}^{-1}$ ), due to the shade promoted by trees, and due to the undisturbed soil structure. Overall, these are good conditions for microorganisms activity, and thus for $\mathrm{N}$ mineralization. On the other hand, leaching that is the main pathway for $\mathrm{N}$ loss, is not probable to occur significantly in orchards due to the deepness of the tree root systems, due to the perennial behavior of apple trees, and due to the warm temperature that occurs in Southern Brazil, especially in the fall and in the winter. These factors allow the plant to take up $\mathrm{N}$ during almost twelve months in a year, even that coming from leaf season senescence, resulting in an increase of native $\mathrm{N}$ use efficiency (NUE). Thus, in orchards developed in these kind of soils, $\mathrm{N}$ fertilization should be small or even eliminated. In addition to reduce production costs, no need for $\mathrm{N}$ application would be desirable for fruit quality because some physiological disorders are associated with high $\mathrm{N}$ fertilization (JANISIEWICZ $\boldsymbol{e t} \boldsymbol{a l}$., 1998).

Concentration of $\mathrm{N}$ in the leaves varied with year and cultivar, and it was associated with crop load. For 'Fuji', the values were always between 2.0 and $2.5 \%$ (table 2), that is considered the normal range (BASSO et al., 1986; COMISSÃO DE FERTILIDADE DO SOLO, 1995); for 'Gala', they were slightly lower, but always above $1,9 \%$ (table 2). In 1991/92 and in 1994/95 growing seasons the mean values of $\mathrm{N}$ in the leaves were higher on 'Fuji' than on 'Gala'; the opposite occurred in the 1993/94 growing season (table 2). For each cultivar, concentration of $\mathrm{N}$ in the leaves was inversely related to crop yield, that is, as the fruit yield increased the $\mathrm{N}$ in the leaves decreased and vice versa (tables 1 and 2).

Growers should be aware, however, in situations where $\mathrm{N}$ release from the soil is lower than in soil conditions mentioned above, most like to occur in soils with low organic matter content, large percent of stones in the plow layer, in shallow soils, and in soils with water $\mathrm{pH}$ under 5.0.

\section{CONCLUSIONS}

Application of $\mathrm{N}$ to the soil in the spring, up to $200 \mathrm{~kg} \mathrm{ha}^{-1}$ year $^{-1}$, did not increase fruit yield and concentration of $\mathrm{N}$ in the leaves for "Gala" and "Fuji" in any of the four years evaluated regardless of high yields obtained, always higher than $50 \mathrm{t} \mathrm{ha}^{-1}$. Average annual fruit yield over seasons varied more for 'Fuji' than for 'Gala', but the mean productivity in the entire period was similar for both cultivars. Concentration of $\mathrm{N}$ in the leaves was inversely associated with crop load, and for both cultivars it was always higher than $1,9 \%$.

\section{REFERENCES}

ADLER, P.R., WILCOX, G.E. Rapid perchloric acid digest methods for analysis of major elements in plant tissue. Communications in Soil Science and Plant Analysis., New York, v. 16, n. 11, p. 1153-1163, 1985. 
BASSO, C., SUZUKI, A. Resposta da macieira Cv. Golden Delicious à adubação nitrogenada. Revista Brasileira de Ciência do Solo, Campinas, v. 16, n. 2, p. 223-227, 1992.

BASSO, C., WILMS, F.W.W. SUZUKI, A. Fertilidade do solo e nutrição da macieira. In: EMPASC (Florianópolis, SC) Manual da cultura da macieira. Florianópolis: EMPASC, 1986. p. 236-265.

COMISSÃO DE FERTILIDADE DO SOLO. Recomendações de adubação e calagem para os estados do Rio Grande do Sul e de Santa Catarina. Passo Fundo: NRS-SBCS, 1995. 224 p.

ERNANI, P.R., DIAS, J., VANZ, L. Application of nitrogen to the soil after fruit harvest has not increased apple yield. Revista Brasileira de Fruticultura, Cruz das Almas, v. 19, n. 1, p. 33-37, 1997

ERNANI, P.R., DIAS, J., BORGES, M. Application of Nitrogen to the soil in different stages had no effect on fruit yield and growth of apple cultivars. Ciência Rural, Santa Maria, v. 30, n. 2, 2000. (No prelo).

FAUST, M. Physiology of temperate zone fruit trees. New York: John Wiley, 1989. 338 p.

FAUST, M., SHEAR, C.B. The effect of calcium on respiration of apples. Journal of American Society for Horticultural Science, Alexandria, v. 97, n. 4, p. 437-439, 1972.

JANISIEWICZ, W.J. , CONWAY, W.S., GLENN, D.M. et al. Integrating biological control and calcium treatment for controlling postharvest decay of apples. HortScience, Alexandria, v. 33, n. 1, p. 105-109, 1998.

LORD, W.J., BAKER, J.H., DAMON JUNIOR., R.A. Soil, tree, and fruit responses to lime and to type and timing of nitrogenous fertilizer applications under Sturdeespur delicious apple trees. Journal of American Society for Horticultural Science, Alexandria, v. 106, n. 5, p. 616-619, 1981.
MERWIN, I.A., STILES, W.C. Orchard groundcover management impacts on apple tree growth and yield, and nutrient availability and uptake. Journal of American Society for Horticultural Science, Alexandria, v. 119, n. 2, p. 209-215, 1994.

MILLAR, P. THOMSON, C.M. The effect of the autumn senescence of leaves on the internal cycling of nitrogen for the spring growth of apple trees. Journal of Experimental Botany, London, v. 220, n. 40, p. 1285-1289, 1989.

O'KENNEDY, B.T., HENNERTY, M.J., TITUS, J.S. The effects of autumn foliar urea sprays on storage forms of nitrogen extracted from bark and wood of apple shoots. Journal of Horticultural Science, Alexandria, v. 50, p. 331 338, 1975.

STILES, W.C. Nitrogen management in the orchard. In: PETERSON, A.B. STEVENS, R.G. (ed.) Tree fruit nutrition. Yakima, WA: Good Fruit Grower, 1994. p. 41-50.

TAGLIAVINI, M., SCUDELlAZI, D., MARANGONI, B. $\boldsymbol{e} \boldsymbol{t} \boldsymbol{a l}$. Nitrogen fertilization management in orchards to reconcile productivity and environmental aspects. Fertilizer Research, Dordrecht, v. 43, p. 93-102, 1996.

TEDESCO, M.J., VOLKWEISS, S.J., BOHNEN, H. Análise de solo, plantas e outros materiais. Porto Alegre: Universidade Federal do Rio Grande do Sul, 1985. 188 p.

TUKEY, R.B. Crop potential: its development and protection. In: Good Fruit Grower (ed.). Pollination fruit set, shortcourse proceedings. Yakima, WA: Good Fruit Grower, 1985. 90 p.

WEINBAUM, S.A., JOHNSON, R.S., DEJONG, T.M. Causes and consequences of overfertilization in orchards. HortTechnology, Alexandria, v. 2, n. 1, p. 112-121, 1992.

WOLK, W.L., LAU, O.L., NEILSEN, G.H., et al. Factors and time of sample collection for correlating storage potential of 'McIntosh', 'Spartan', and 'Golden Delicious' apples. Journal of American Society for Horticultural Science, Alexandria, v. 123, n. 1, p. 104-109, 1998. 